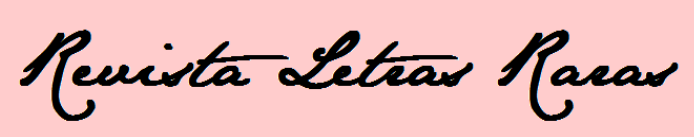

ISSN: 2317-2347 - v.6, n.1 (2017)

\title{
Retrato de vinte anos
}

Leandro Marlon Barbosa Assis ${ }^{*}$

A anestesia da alma é o pior dos processos. Você se torna insensível a dor do outro e a tua. Se o José acorda quatro da manhã para conseguir chegar no emprego às sete, tu dizes que ele precisa se esforçar mais. Se o José, nesse mesmo trajeto, entrar num ônibus caindo aos pedaços e pagando quatro reais para ficar dez minutos nele para não andar pelas ruas escuras e perigosas da Baixada Fluminense, tu dizes que ele precisa se esforçar mais para sair deste lugar. Se o José, vejam só, correr para subir as escadarias do metrô da Pavuna e lutar - sim, ele precisa brigar caso queira se sentar -, tu dizes que ele precisa sair mais cedo. José viajará em pé, pois viu uma senhora de cabelos grisalhos sendo sufocada pela multidão de rostos anestesiados pela dor do outro. A viagem é de uma hora e, vejam só, o ar condicionado do vagão é insuficiente pela quantidade de insensíveis corpos quentes de corações frios. O sol queima as costas de José no mesmo local em que ficariam as marcas de uma escravização moderna. O peso da tristeza no coração de José está nos pedidos dos três filhos por comida, brinquedos e lazer. Nessa semana estreou o filme de herói da moda e José tem vendido cerveja na praça todas as noites para conseguir dar aos filhos algum oásis no sofrimento mundano. $\mathrm{O}$ vagão segue enchendo na mesma medida que a alegria se evanesce do olhar do trabalhador. A massa de gado segue as placas e José olha para o alto, esperando dias melhores. Contudo, o que sobram são filas e mais uma condução lotada. Tu dizes que ele precisa se esforçar mais, mas o curioso é tua rotina. Acorda tranquilamente com a certeza de que em meia hora chegará na companhia. Toma um banho morno com sais diversos e cremes de rejuvenescimento. Escolhe a roupa de marca da moda com o tom de cor que combina com o par de óculos. Vai até a garagem e dá partida no carro. Acelera e freia no trânsito constante e xinga esse povo que não deveria estar ali. Quase atropela um senhor que corria para chegar na fila do ônibus. "Essa gente que destrói o país por causa da previdência e do bolsa família". Tu abres do vidro e manda o senhor prestar atenção e voltar para o quinto dos infernos que é o lugar dele. José segue em pé e já pensa em como fazer na volta: a empresa terceirizada dele não paga salários há quatro meses e deposita o dinheiro da passagem para que ele não falte,

\footnotetext{
* Mestrando do Programa de Pós-Graduação em Mídia e Cotidiano da Universidade Federal Fluminense PPGMC/UFF vinculado a linha de pesquisa 'Linguagens, representações e produção de sentidos'; bacharel em Jornalismo pela Universidade Federal Rural do Rio de Janeiro-UFRRJ; licenciado em História pela Universidade Federal Rural do Rio de Janeiro-UFRRJ; e Professor Regente I na Secretaria de Estado de Educação do Rio de Janeiro- SEEDUC. Endereço eletrônico: leandro88marlon@gmail.com
} 


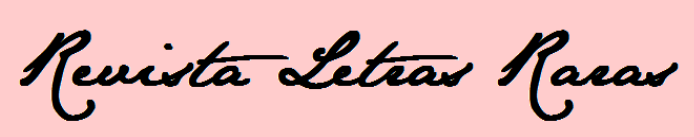

ISSN: 2317-2347 - v.6, n.1 (2017)

afinal, não teria motivos. Tu estacionas e aguardas o elevador; entras e diz somente o andar para a moça ascensorista que lhe deu o bom dia usual e simpático de todas as manhãs. José chega no serviço atrasado e toma conhecimento de que o supervisor já quer falar com ele. Começa o serviço e, na hora do almoço, come um pão com manteiga de casa enquanto vai ao encontro do superior. "A crise do Estado está forte e por isso precisamos fazer cortes, então...". José perde o chão, o emprego, a esperança e toda a alternativa de vida. José começa a pensar no FGTS que aliviará algumas contas atrasadas - incluindo o aluguel que já tem ordem de despejo com data marcada. Tu dizes que o senhor a sua frente está demitido, mesmo com o salário atrasado e trabalhando. Tu dizes que ele poderia procurar um curso para se aperfeiçoar no tempo livre. Tu realmente acreditas que ele é o culpado por essa situação. Tu dizes quase tudo, menos que a empresa não recolheu o fundo que era direito daquele senhor. Tu se sentes pleno na mesa da supervisão enquanto José se sente no chão pela sociedade que insiste em mentir na meritocracia.

E isso não é tudo. Existem milhares de 'José' que são explorados todos os dias pelas empresas terceirizadas que ampliaram seus poderes em 2017. O Congresso de um país de bananas governadas por sacanas desferiu mais um golpe nos direitos trabalhistas e sociais. $\mathrm{O}$ projeto de lei da terceirização somado a Reforma da Previdência apenas favorece aqueles insensíveis movidos pelo amor ao dinheiro e que se esquecem da materialidade da vida. Os filhos de José não poderão alcançar uma educação plena, pois os governos - em todos os níveis - oferecem estruturas defasadas, com risco a vida e sem remuneração adequada aos profissionais que lá trabalham - e que tende a piorar no cenário de um teto de gastos que congela o país por vinte anos (e faz sentido tornar o país a forma mundana dos congelados corações). E mais: o pseudo governo, instalado após o processo circense chamado de impeachment, decidiu tocar uma reforma do Ensino Médio que favorecerá à elite letrada e desalmada enquanto formará uma base trabalhadora acrítica e pronta à obediência nos moldes do que é o sindicalismo que só tem força no nome - e talvez no congresso com um líder em diminutivo que atribui muito sentido aos insensíveis.

Se estes contextos e situações não tocam o coração e motivam a lutar, talvez você seja aquele interlocutor de segunda pessoa da história. Porém, se levas a vida como José e pensas como "tu", talvez sofra de Síndrome de Estocolmo e bata panelas enquanto um governo eleito democraticamente se pronunciava. Desligue o Jornal Nacional e vá ver/viver as ruas e perceberá que o estado de exceção que se instalava nas favelas tomou o asfalto e que os Black Blocs não são o inimigo. 
Reuista Letear Macar

ISSN: 2317-2347 - v.6, n.1 (2017)

Recebimento: 05/04/2017

Aceite: 20/06/2017 